\title{
EFFECT OF DIETARY SUPPLEMENTAL AMINO ACIDS WITH OR WITHOUT PROBIOTIC ON PRODUCTIVE PERFORMANCE OF BROILER CHICKS El-Serwy, Amina A. ${ }^{1}$; I. Elwardany ${ }^{2}$ and A. K. M. Ibrahim ${ }^{1}$ 1- Poultry Production Dept., Fac. Agric. Mansoura Univ. 2- Poultry Production Dept., Fac. Agric. Ain shams Univ.
}

\begin{abstract}
Three hundred and sixty, 2 weeks old, unsexed Cobb chicks were used in this study to evaluate the effect of low protein diets fortification with amino acids and Probiotic on productive performance, carcass traits and some blood constituents.

Two control diets (19\% C.P.) and (17\% C.P.) and eight experimental groups depending on two levels of Lysine and Methionine $(0.1$ or $0.2 \%)$ supplemented to the $17 \%$ protein diets with or without supplementation of probiotic $(1.0 \times 109$ C.F.U.UP Bacillus subtilis; Saccharomyces Cerevisiae) were investigated.

Chicks fed $17 \%$ CP diet with adding $0.2 \%$ methionine plus probiotic (Treatment 10) showed significantly $(P<0.05)$ highest body weight, body weight gain and consumed the lowest significantly $(\mathrm{P}<0.05)$ amount of feed. Furthermore, the same treatment showed highest value of carcass quality except for gizzard. However there was no significant effect of treatment on plasma total protein.
\end{abstract}

Keywords: Low protein diet, amino acids, Probiotic, broiler.

\section{INTRODUCTION}

The feeding cost of poultry production are generally the most expensive item, particularly the protein units cost.

Protein is a critical component of poultry rations, and along with the other major nutrient classes of carbohydrates, fats, vitamins, minerals, and water it is essential for life (Cheeke, 2005; North and Bell; 1990, Pond et al, 1995).

Therefore, many workers aimed to reducing feed costs by decreasing dietary protein, levels, but the question is how they can achieve this goal without adverse impact on performance.

Amino acid requirements have been shown to fluctuate with the level of protein in the diet; specifically, the amino acid requirement, as a percentage of the diet, will increase with the concentration of dietary crude protein (Hurwitz et al., 1998; Morris et al., 1999; Sklan and Noy, 2003).

Addition of amino acids to diets permits a reduction in dietary protein content and at the same time provides the needs of all indispensable amino acids required by chicks with an optimal amino acid profile (Sklan and Noy, 2003). 
It is known that broiler chicks fed diets marginal in protein but fortified with Methionine or Methionine plus lysine will perform as well as these fed a diet higher in its protein contents (Morris et al., 1999).

The availability of commercial synthetic amino acids allow this to be done with low protein diets by avoiding an excess of each amino acid requirement.

Results obtained by many investigators indicate that protein utilization efficiency was improved as a consequence of minimizing excess levels of essential amino acids in the diet. Recently, it is observed that chicks fed low-protein diets supplemented with amino acids had similar performance as those fed a $23 \%$ crude protein diet (Hurwitz et al., 1998).

Probiotic have been introduced as a feed additive. Some trials have shown that this component improves bird performance and causes a drop in mortality rates (El-Ghamry et al., 2002).

Saccharomyces cereviside contains large amounts of yeast metabolites. These metabolites had the ability for inhibiting harmful bacteria, altering microbial metabolism and decrease intestinal $\mathrm{pH}$ and then used as probiotics (Makled, 1991 and Miles and Bootwella, 1991).

The present study aimed to investigate the effect of low protein diets with amino acids and probiotic supplementation on performance of broiler chickens.

\section{MATERIALS AND METHODS}

The current study was carried out at the Experimental and Research Farm of Poultry, Poultry Production Department, Faculty of Agriculture, Mansoura University. The main objective was to investigate the effect of low protein diets fortification with amino acids and Probiotic on productive performance of broiler chicks, carcass traits, some blood constituents and economic efficiency.

\section{Birds and management:}

A total of 360 , one day old Cobb-500 broiler chicks were used in the present study. They were fed a commercial starter diet containing $21 \%$ crude protein and $3000 \mathrm{kcal} \mathrm{ME} / \mathrm{kg}$ of diet from hatching to two weeks of age. At the beginning of the third week, chicks were randomly and equally distributed into ten groups of 36 chicks in three replicates, 12 chicks each. These groups were allotted to the following experimental treatments:

$\mathrm{T}_{1}$ : birds were fed a basal diet containing $19 \%$ crude protein and served as a normal control group (Table1).

T2: birds were fed a basal diet containing $17 \%$ crude protein as a low protein diet group.

T3 and T4: birds were fed the low crude protein diet plus 0.1 or $0.2 \% \mathrm{~L}$ lysine. 
T5 and T6: similar to T3 and T4 but with $1.5 \mathrm{mg} / \mathrm{kg}$ diet of supplemental probiotic (Bacillus subtilis; saccaromyces cerevisiae).

T7 and T8: birds were fed the low crude protein diets (17\%CP) plus 0.1 or $0.2 \%$ DL- Methionine, respectively.

T9 and T10: Similar to T7 and T8 but with the supplemental probiotic $(1.5 \mathrm{mg} / \mathrm{kg}$ diet).

- The composition and calculated analysis of the basal diets are shown in Table-1.

Feed and water were offered ad libitum during the experimental period which lasted for five weeks (3-7 wks of age). Chicks of all groups were kept under similar hygienic, environmental and managerial conditions.

Table (1): Composition and calculated analysis of the experimental diets.

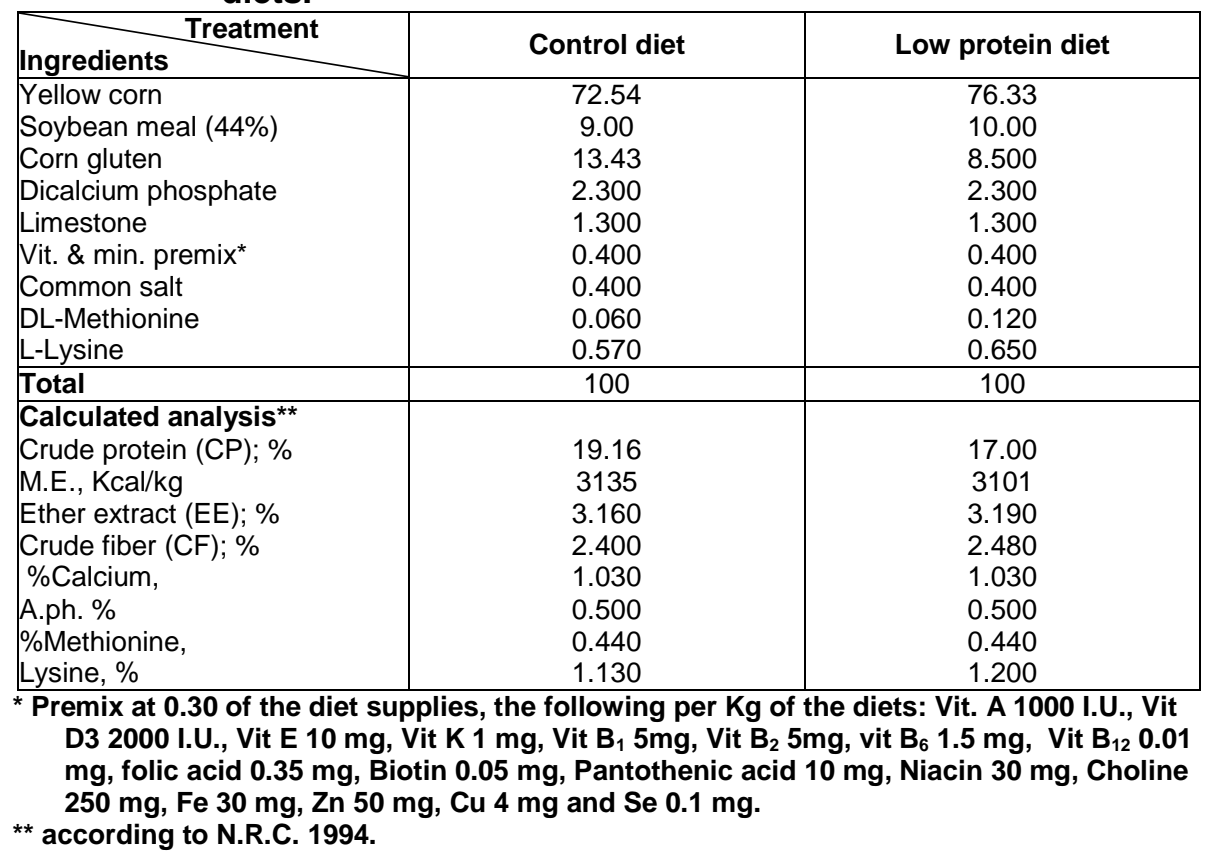

\section{Characteristics investigated:}

All birds were individually weighed at the beginning of the experimental period and then at weekly intervals to determine live body weight and body weight gain.

Feed consumption (g/bird/day) and feed conversion ratio (feed: gain, g) were recorded weekly for each treatment.

At the end of the experimental period (7 weeks of age) six chickens from each treatment were randomly selected, weighed and slaughtered to complete bleeding, followed by plucking the feather and then reweighed. 
Dressing percentage was determined after removal of head, viscera, and shanks. Liver and gizzard were weighed, and expressed as a percentage of the live body weight. Blood samples from three birds per treatment were taken at slaughtering in heparinized tubes and centrifuged immediately for 10 min at 4000 r.p.m to separate blood plasma. The plasma samples were decanted in Ependorf tubes and plasma samples were kept frozen at $-20^{\circ} \mathrm{C}$ until the time of analysis. Blood glucose was determined according Trinder (1969), total protein (Doumas, 1975), albumin (Doumas et al., 1971), cholesterol (Allain et al., 1974) Glutamic-Oxaloacetic Transaminase (GOT) and Glutamic-Pyruvic Transaminase (GPT) (Reitman and Frankel, 1957) were determined by using available commercial kits.

Data were statistically analyzed (SAS, 1990) by the application of the least square procedure. Differences among treatments means were done by using Duncan's multiple range test (Duncan, 1955).

\section{RESULTS AND DISCUSSION}

\section{Live body weight:}

The effects of experimental treatments on body weight of broiler chicks are presented in Table (2). The initial body weight at the beginning of the third week of age, ranged from 413.33 to $416.67 \mathrm{~g}$ without significant differences among treatments. At 5 weeks of age, the control $\left(T_{1}\right)$ and $T_{8}, T_{9}$ and $T_{10}$ treatment groups showed the highest $(p \geq 0.05)$ mean of body weight. The lowest values were recorded for the other treatment groups that fed $17 \%$ either with or without supplementations.

At 7 weeks of age, broilers fed the experimental diet (17\% CP) with different additions (from $T_{5}$ up to $T_{10}$ ) attained significantly higher body weight. However, broiler fed the control diet (19\% CP) showed also similar body weight comparable to the highest values observed.

These results are in agreement with the findings by Tolba et al. (2004) who found significant increase in body weight at 35, 42 and 49 days of age compared with control group of those birds fed on a diet supplemented with probiotics.

However, El-Ghamry et al. (2002) indicated that there were no significant differences in live body weight and weight gain between the broiler chicks fed a basal diet with $0.1 \%$ or $0.2 \%$ yeast culture (Saccharomyces cerevisiae).

\section{Body weight gain:}

At the period from 3 to 5 weeks of age, the $T_{8}$ and $T_{10}$ followed by $T_{1}$ and $T_{9}$, respectively, showed the highest significantly body weight gain than other treatments. While, treatment $(19 \% \mathrm{CP})$ had significantly lower body weight gain than the other groups through from $5-7$ weeks of age. 
J. Animal and Poultry Prod., Mansoura Univ., Vol.3 (3), March, 2012 2 
Treatment $10(17 \% \mathrm{CP}+0.2$ Methionine + probiotic) and treatment 8 $(17 \% \mathrm{CP}+0.2$ Methionine) showed the highest of body weight gain at the period from $3-7$ weeks of age, respectively (1683.33 and 1681.67), as shown in Table 2.

In the same trend, Salim (2004) studied the effect of using probiotics on growth performance of broiler chicks from $7-49$ days of age. He found significant increase in body weight gain compared with the control during the most of the experimental periods

Feed intake:

During the first period of the experiment ( $3-5$ weeks of age), broilers group received diet contained $17 \% \mathrm{CP}+0.2$ methionine with probiotic gave the highest value for feed intake $(1395 \mathrm{~g})$, while the lowest feed intake (1300 $\mathrm{gm}$ ) was for broiler groups fed $T_{2}$ to $T_{6}$ as compared to those receiving other experimental diets. Treatment $3(17 \% \mathrm{CP}+0.1$ lysine $)$ had significantly higher feed intake $(2000.33 \mathrm{gm})$ than those fed other experimental diets during the second period of the experiment ( $5-7$ weeks).

Overall the experimental period ( $3-7$ weeks of age), birds fed on $17 \% \mathrm{CP}+0.1 \%$ methionine or $17 \% \mathrm{CP}$ alone recorded the highest values for feed intake (3363.33 or $3362.33 \mathrm{gm}$ ) when compared to the other dietary treatments.

No significant effect due to experimental treatment at periods from 5 -6 and $6-7$ weeks of age.

These results are in agreement with Tolba et al. (2004) who found significant increases in feed intake at 35,42 , and 49 days of age compared with control. But, Abd-Elsamee (2001) showed that adding probiotic to broiler chick diets recorded significantly higher feed intake than those fed diets without supplementation during 1-4 and 5-7 weeks of age.

Feed conversion ratio:

The effects of experimental treatments on feed conversion ratio of broiler presented in Table (2).

The best FCR was obtained by birds fed $T_{10}, T_{8}$ or $T_{1}$ while the worst FCR (1.90) was obtained by $T_{2}(17 \% \mathrm{CP}$ alone) through the first period of the experimental ( $3-5$ wks).

It is clear that, value FCR were significantly impaired with birds fed 19 or $17 \%$ CP diet when compared with the other experimental diets during the second period $(5-7$ weeks of age.

No significant effect due to experimental treatment at periods from 6 -7 and $3-7$ weeks of age.

Blood parameters:

The effects of experimental treatments on blood parameters of broiler chicks are presented in Table (3).

The results revealed that control treatment (19\% protein) predeceased significant increased in the concentration of glucose, percentage of hemoglobin and activity of AST and ALT were negatively affected compared with their control counterparts. 
J. Animal and Poultry Prod., Mansoura Univ., Vol.3 (3), March, 2012 3-4 
There was significant effect due to experimental treatment on total protein and cholesterol.

The same trend found by El-Ghamry et al. (2002) showed that when broiler chicks fed on diets with 2 levels of yeast culture $(0.1$ and $0.2 \%)$, the concentration of plasma total protein, albumin and globulin were not affected markedly with the experimental diets

\section{Carcass quality:}

The effects of different treatment on carcass traits (as percent of live body weight) are shown in (Table 4)

Results indicated that no significant effect among treatments on live body weight, however, percentage of carcass traits including dressing carcass, heart, liver, abdominal fat were increased significantly by treatment $10\left(17 \% \mathrm{CP}+\right.$ probiotic). Treatments $\left(\mathrm{T}_{3}, \mathrm{~T}_{4}\right.$ and $\left.\mathrm{T}_{5}\right)$ showed highest significantly percentage of gizzard as compared to the other treatments.

These results agreement with found by Salim (2004) studied the effect of adding probiotics (Premalac, Lacture and Biobadus) of the diet to broiler chicks diets on carcass characteristics. They found that the average values of internal organs as a percentage of body weight (liver, gizzard, heart, spleen, thymus and bursa) increase in probiotic constituents compared to control group.

\section{REFERENCES}

Abd-Elsamee, M. O. (2001). Broiler performance as affected by etude protein, lysine and a-probiotic. Egypt. Poult Sci, 21: 162-943.

Allain, C. A.; L.S. Poon; C.S.G. Chang; W. Richmond and P. C. Fu (1974). Enzymatic determination of total serum cholesterol. Clinical chemistry, 20: $470-475$.

Miles, R. D. and S. M. Bootwella (1991). Direct-feed microbial in animal production. National feed ingredients Association. Desmomes, lowa, USA.

Cheeke, P.R. (2005). Livestock Feeds and Feeding. 3rd Ed. Pearson Prentice Hall. Upper Saddle River, New Jersey.Cheeke, 2005.

Doumas, B.I.; W. Watsn and H. Biggs (1971). Albumin standards and the measurements of serum albumin with bromocresol green. Clin. Chim.. Acta., $31: 87-96$.

Doumas, B. I. (1975). Standards for total serum protein assays-a collaborative study . Clin. Chem.., 21(8): $1159-1166$.

Duncan, D.B. (1955). Multiple range and multiple F. tests. Biometrics, 11: 142.

El-Ghamry, A. A.; G. M. El-Mallah and A. T. El-Yamny (2002). The effect of incorporating yeast culture, Nigella sativa seeds and fresh garlic in broiler diets on their performance. Egypt. Poult. Sci. J. Vol. 22(II): 445 -459 . 
Hurwitz, S., D. Sklan, H. Talpaz and I. Plavnik (1998). The effect of dietary protein level on the lysine and arginine requirements of growing chickens. Poultry Sci. 77:689-696.

Makled, M. N. (1991). The potentials of probiotics in poultry feeds. A review. 3rd Scientific Symp. For animal, poultry and fish nutrition. Sakha, Kafr El-Sheikh, Egypt. 54- 68 pp.

Morris, T.R., R.M. Gous and C. Fisher (1999). An analysis of the hypothesis that amino acid requirements for chicks should be stated as a proportion of dietary protein. World's Poult. Sci. J. 55: 7-22.

North, M.O. and D.D. Bell (1990). Commercial Chicken Production Manual. 4th Ed.Van Nostrand Reinhold. New York.North and Bell; 1990.

Pond, W.G., D.C. Church and K.R. Pond (1995). Basic Animal Nutrition and Feeding. 4th Ed. John Wiley and Sons, Inc. Canada.

Reitman, S. and Frankel, S. (1957). Combination of Test Glutamic-Pyruvic Transaminase and Glutamic-Oxaloacetic Transaminase. Amer. J. Clin. Path., $28: 56$.

SAS Institute (1990). SAS® User's Guide. Statistics version $6^{\text {th }}$ ed., SAS Intstitute Inc., NC. USA.

Salim , I. H. (2004). Effect of Dietary protiun and some feed additives on Broiler performance. M.SC Thesis, Department of Animal production, Faculty of Agriculture Cairo Univerity, Giza, Egypt.

Sklan, D. and Y. Noy (2003). Crude protein and essential amino acid requirements in chicks during the first week posthatch. Br. Poultry Sci. 44(2): 266-274.

Tolba, A. A., H. M. M. Sabry and G.G. Medani (2004). Effect of micrrobial probiotics on performance of broiler chicks under normal or heat stress conditions: 2- Bacteria on centration or yeast culture. Egypt. Poult. Sci ., 24:333-349.

Trinder, P. (1969). Determination of glucose in blood using glucose oxidase with an alternative oxygen acceptor. Ann. Clin. Biochem. 6:24-27.

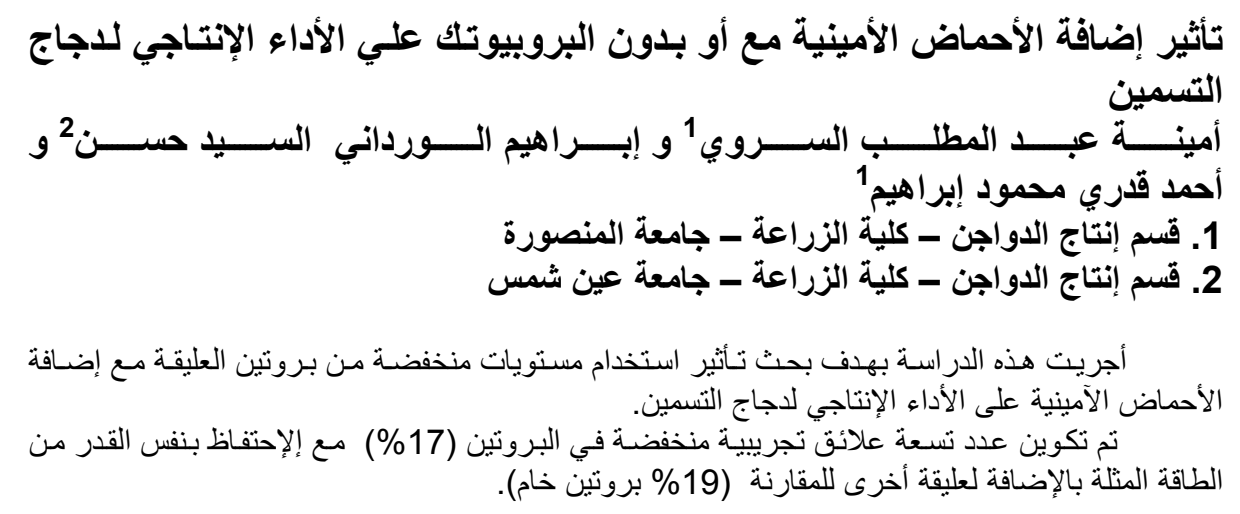




\section{El-Serwy, Amina A. et al.}

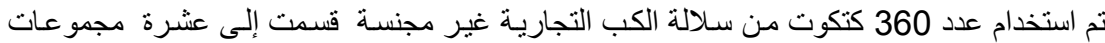

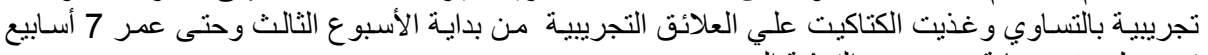
تحت ظروف رعاية موحدة مع التغذية الحرة.

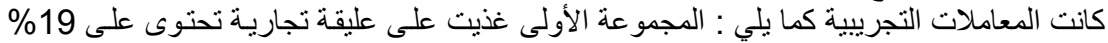

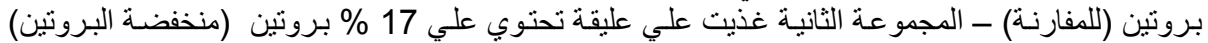

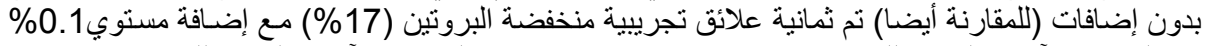

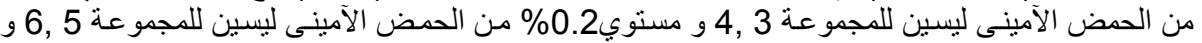

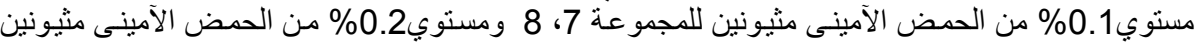

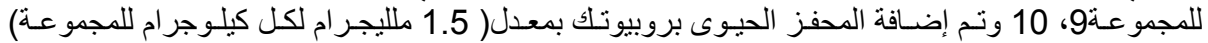

للمجمو عات رقم 4 ، 6 ، ، 8 ، 10

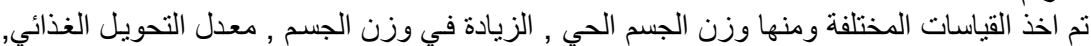

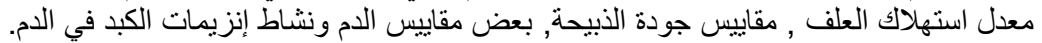

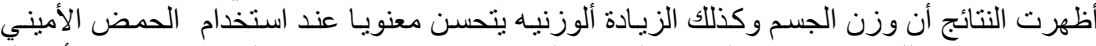

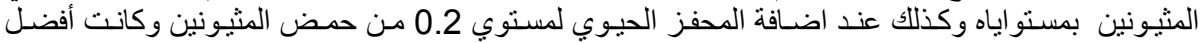
تؤيح النتائج أيضا أن معامل التحويل الغذائي كان أحسن مـا يمكن في المجموعات التي غذيت على مستوي 17 \% يروتين ويمكن تلخيص النتائج المتحصل عليه خلئ خلال الفترة التجريبية فيما يلي :

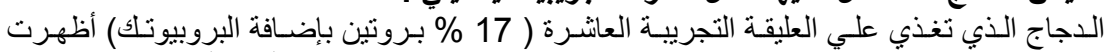

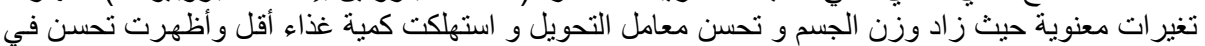

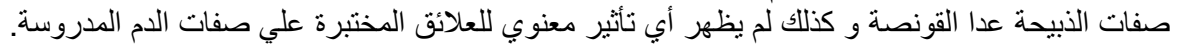

كلية الزراعة ـ جامعة المنصورة قام بتحكيم البحث كلية الزراعة - جامعة عين شمس الزعس 
J. Animal and Poultry Prod., Mansoura Univ., Vol.3 (3), March, 2012 
J. Animal and Poultry Prod., Mansoura Univ., Vol.3 (3): 157 - 166, 2012

Table (2): Effect of dietary protein levels and supplemental amino acids with or without probiotic on broiler performance (Means \pm SE).

\begin{tabular}{|c|c|c|c|c|c|c|c|c|c|c|}
\hline \multirow{2}{*}{$\begin{array}{c}\text { Broiler } \\
\text { performance }\end{array}$} & \multicolumn{10}{|c|}{ Treatment $(\mathrm{T})$} \\
\hline & T1 & T2 & T3 & T4 & \begin{tabular}{l|l|} 
T5 \\
\end{tabular} & T6 & $\mathrm{T} 7$ & T8 & T9 & T10 \\
\hline $\begin{array}{l}\text { Body weight } \\
\text { 3wk } \\
5 w k \\
7 w k\end{array}$ & $\begin{array}{c}413.33 \pm 6.01 \\
1225.00 \pm 12.58^{\mathrm{a}} \\
2048.33 \pm 29.49^{\mathrm{ab}}\end{array}$ & \begin{tabular}{|c|}
$413.33 \pm 8.82$ \\
$1140.00 \pm 20.21^{1}$ \\
$1998.33 \pm 6.01^{\circ}$
\end{tabular} & $\begin{array}{c}416.67 \pm 8.82 \\
1155.00 \pm 22.19^{b} \\
2035.00 \pm 21.79^{b}\end{array}$ & $\begin{array}{c}415.00 \pm 2.89 \\
1150.00 \pm 5.77^{b} \\
2038.33 \pm 6.01^{\circ}\end{array}$ & $\begin{array}{c}413.33 \pm 6.01 \\
1158.33 \pm 15.90^{b} \\
2060.00 \pm 30.55^{\mathrm{ab}}\end{array}$ & $\begin{array}{c}411.67 \pm 3.33 \\
1166.67 \pm 7.26^{6} \\
2056.67 \pm 7.26^{a b}\end{array}$ & $\begin{array}{c}413.33 \pm 4.44 \\
1166.67 \pm 12.02^{b} \\
2058.33 \pm 6.01^{b}\end{array}$ & $\begin{array}{c}413.33 \pm 1.67 \\
1241.67 \pm 33.46^{a} \\
2095.00 \pm 2.89^{a}\end{array}$ & & \\
\hline $\begin{array}{l}\text { Weight gain } \\
3-5 w k \\
5-7 w k \\
3-7 w k\end{array}$ & \begin{tabular}{|}
$811.67 \pm 13.51^{\mathrm{b}}$ \\
$823.33 \pm 10.14 \mathrm{c}$ \\
$1635.00 \pm 27.54^{\mathrm{abc}}$ \\
\end{tabular} & $\begin{array}{c}726.67 \pm 9.28^{c} \\
858.33 \pm 8.82 b \mathrm{bc} \\
1585.00 \pm 2.89^{\circ}\end{array}$ & \begin{tabular}{|c}
$738.33 \pm 18.33^{c}$ \\
$880.00 \pm 12.58 b$ \\
$1618.33 \pm 13.64^{\circ}$
\end{tabular} & \begin{tabular}{|c|}
$735.00 \pm 4.24^{c}$ \\
$888.33 \pm 7.26 a b$ \\
$1623.33 \pm 7.26^{b c}$ \\
\end{tabular} & \begin{tabular}{|}
$745.00 \pm 12.00^{c}$ \\
$901.67 \pm 14.53 \mathrm{a}$ \\
$1646.67 \pm 36.00^{\mathrm{ab}}$ \\
\end{tabular} & $\begin{array}{c}755.00 \pm 8.88^{\mathrm{c}} \\
890.00 \pm 7.64 \mathrm{a} \\
1645.00 \pm 7.64^{\mathrm{ab}}\end{array}$ & \begin{tabular}{|c}
$753.33 \pm 13.51^{\circ}$ \\
$891.66 \pm 8.82 \mathrm{a}$ \\
$1645.00 \pm 5.77^{\mathrm{b}}$ \\
\end{tabular} & $\begin{array}{c}828.33 \pm 16.46^{\mathrm{a}} \\
853.33 \pm 6.89 \\
1681.67 \pm 4.41^{\mathrm{a}}\end{array}$ & & \begin{tabular}{|c}
$843.33 \pm 14.89^{a}$ \\
$840.00 \pm 13.02 b \mathrm{bc}$ \\
$1683.33 \pm 7.26^{a}$
\end{tabular} \\
\hline $\begin{array}{l}\text { Feed inake } \\
3-5 w k \\
5-7 w k \\
3-7 w k\end{array}$ & $\mid \begin{array}{c}1363.67 \pm 8.37^{20} \\
1982.34 \pm 14.24^{20} \\
3346.00 \pm 31.13^{\mathrm{a}}\end{array}$ & $\begin{array}{c}1380.00 \pm 6.01^{\mathrm{a}} \\
2000.33 \pm 10.14^{\mathrm{a}} \\
3362.33 \pm 13.64^{\mathrm{a}}\end{array}$ & $\begin{array}{l}1358.33 \pm 3.33^{\text {ab }} \\
1958.33 \pm 3.33^{\mathrm{b}} \\
3316.67 \pm 6.67^{\mathrm{b}}\end{array}$ & $\begin{array}{c}1344.67 \pm 8.8^{\mathrm{b}} \\
1960.00 \pm 3.33^{\mathrm{b}} \\
3305.00 \pm 21.79^{\mathrm{b}}\end{array}$ & & $\begin{array}{l}1300.00 \pm 12.03^{\mathrm{c}} \\
1961.67 \pm 11.677^{\mathrm{b}} \\
3261.67 \pm 4.41^{\mathrm{b}}\end{array}$ & $\begin{array}{c}1393.33 \pm 5.00^{\mathrm{a}} \\
1970.00 \pm 7.26^{\mathrm{b}} \\
3363.33 \pm 4.41^{\mathrm{a}}\end{array}$ & $\begin{array}{c}1380.00 \pm 6.01^{\mathrm{a}} \\
1980.00 \pm 10.14^{2 b} \\
3360.00 \pm 12.58^{\mathrm{a}}\end{array}$ & & $\begin{array}{l}1958.34 \pm 6.6 \\
3353.33 \pm 6.0\end{array}$ \\
\hline $\begin{array}{l}\text { Feed conv. } \\
3-5 w k \\
5-7 w k\end{array}$ & & & & & & & & & $\begin{array}{l}1.72 \pm 0.009^{b} \\
2.26 \pm 0.006^{b} \\
2.00 \pm 0.001^{b}\end{array}$ & $\begin{array}{l}1.65 \pm 0.005^{b} \\
2.33 \pm 0.017^{\mathrm{a}} \\
1.99 \pm 0.003^{\mathrm{b}}\end{array}$ \\
\hline
\end{tabular}

T1: Control group, $19 \%$ CP, T2: Control group, $17 \%$ CP, T3: $17 \%$ CP $+0.1 \%$ Lysine, T4: $17 \%$ CP +0.2\%Lysine, T5: T3 + probiotic (1.5mg/kg diet ), T6: T4 + probiotic (1.5mg/kg diet ), T7: $17 \%$ CP + 0.1 Methionene, T8: 17\% CP + 0.1 Methionene, T9: T7 + probiotic (1.5mg/kg diet ), T10: $\mathrm{T} 8+$ probiotic $(1.5 \mathrm{mg} / \mathrm{kg}$ diet $)$

$a, b, c, \ldots . . m e a n s$ within rows with different superscripts differ significantly $(p \leq 0.05)$. 
Table (3): Effect of dietary protein levels and supplemental amino acids with or without probiotic on blood analyses (Means $\pm \mathrm{SE}$ ).

\begin{tabular}{|c|c|c|c|c|c|c|c|c|c|c|}
\hline \multirow{2}{*}{$\begin{array}{c}\text { Blood } \\
\text { analyses }\end{array}$} & \multicolumn{10}{|c|}{ Treatment (T) } \\
\hline & T1 & T2 & T3 & T4 & T5 & T6 & T7 & T8 & T9 & T10 \\
\hline Globulin & $235.33 \pm 21.57^{\mathrm{a}}$ & $201.33 \pm 10.93^{\text {ab }}$ & $205.17 \pm 1.42^{\mathrm{ab}}$ & $199.00 \pm 9.93^{\text {ab }}$ & $210.83 \pm 6.41^{\text {ab }}$ & $191.67 \pm 8.96^{6}$ & $224.00 \pm 6.61^{\text {ab }}$ & $209.83 \pm 16.62^{\text {ab }}$ & $195.50 \pm 9.29^{\circ}$ & $208.07 \pm 4.13^{\text {क }}$ \\
\hline Total protein & $3.88 \pm 0.51$ & $3.48 \pm 0.008$ & $3.90 \pm 0.009$ & $3.59 \pm 0.007$ & $3.58 \pm 0.12$ & $3.60 \pm 0.32$ & $3.56 \pm 0.009$ & $3.48 \pm 0.007$ & $3.81 \pm 0.14$ & $3.65 \pm 0.006$ \\
\hline & $\begin{array}{c}10.18 \pm 0.48^{\mathrm{a}} \\
\end{array}$ & 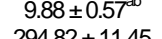 & $9.36 \pm 0.34^{\infty}$ & $9.38 \pm 0.66^{\circ \mathrm{c}}$ & $8.68 \pm 0.33^{000}$ & $\begin{array}{c}7.76 \pm 0.27^{\circ} \\
31576\end{array}$ & $\begin{array}{c}8.30 \pm 0.32^{\mathrm{\omega \omega}} \\
\end{array}$ & $\begin{array}{r}9.73 \pm 0.53^{20} \\
31709+3232\end{array}$ & $9.20 \pm 0.005^{\circ \mathrm{c}}$ & $9.05 \pm 0.18^{\mathrm{abc}}$ \\
\hline $\begin{array}{l}\text { Glucose } \\
\text { GPT }\end{array}$ & $\begin{array}{c}274.72 \pm 13.95 \\
33.67 \pm 2.17^{\mathrm{a}}\end{array}$ & $\begin{array}{r}294.82 \pm 11.45 \\
26.17 \pm 1.96^{c}\end{array}$ & $\begin{array}{l}283.32 \pm 8.87 \\
24.33 \pm 3.28^{\text {c }}\end{array}$ & $\begin{array}{l}321.81 \pm 7.65 \\
20.33 \pm 1.96^{60}\end{array}$ & $\begin{array}{l}316.28 \pm 1.66 \\
26.67 \pm 3.09^{c}\end{array}$ & $\begin{array}{l}315.76 \pm 5.34 \\
17.50 \pm 0.87^{\circ}\end{array}$ & $\begin{array}{c}289.63 \pm 13.23 \\
22.67 \pm 1.74^{\text {bc }}\end{array}$ & $\begin{array}{l}317.99 \pm 33.38 \\
22.67 \pm 1.74^{\text {ce }}\end{array}$ & $\begin{array}{c}303.75 \pm 34.54 \\
18.33 \pm 2.62^{c}\end{array}$ & $\begin{array}{l}302.01 \pm 5.95 \\
23.59 \pm 1.11^{\mathrm{bc}}\end{array}$ \\
\hline GOT & $247.83 \pm 15.24^{\circ}$ & $204.33 \pm 7.84^{b c}$ & $193.33 \pm 15.83^{\text {bc }}$ & $187.50 \pm 15.16^{b c}$ & $189.67 \pm 1.96^{\mathrm{bc}}$ & $190.83 \pm 1.48^{b \mathrm{Co}}$ & $166.67 \pm 13.75^{\circ}$ & $213.00 \pm 8.54^{b}$ & $166.33 \pm 12.37^{\circ}$ & $195.50 \pm 5.60^{\mathrm{bc}}$ \\
\hline
\end{tabular}

T1: Control group, $19 \%$ CP, T2: Control group, $17 \%$ CP, T3: 17\% CP $+0.1 \%$ Lysine, T4: 17\% CP +0.2\%Lysine, T5: T3 + probiotic (1.5mg/kg diet ), T6: T4 + probiotic (1.5mg/kg diet), T7: 17\% CP + 0.1 Methionene, T8: 17\% CP + 0.1 Methionene, T9: T7 + probiotic (1.5mg/kg diet ), T10: $\mathrm{T} 8+$ probiotic $(1.5 \mathrm{mg} / \mathrm{kg}$ diet $)$

$a, b, c, \ldots . . m e a n s$ within rows with different superscripts differ significantly $(p \leq 0.05)$.

Table (4): Effect of dietary protein levels and supplemental amino acids with or without probiotic on carcass traits(Means \pm SE).

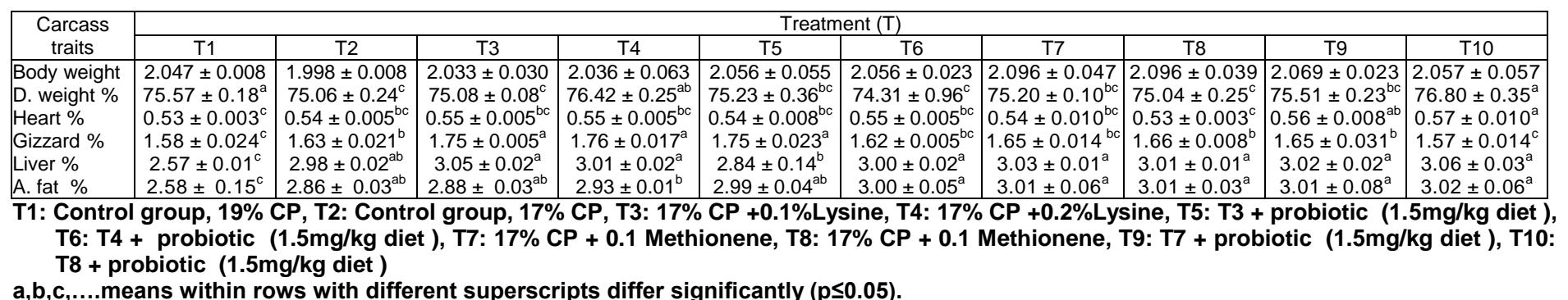

